\title{
Karamunting (Rhodomyrtus tomentosa) Callus Induction In Vitro
}

\author{
Mela Rahmah ${ }^{1}$, Aswaldi Anwar ${ }^{2 *}$, and Etti Swasti ${ }^{3}$
}

\author{
${ }^{1}$ Department of Agronomy, Faculty of Agriculture Andalas University, Indonesia \\ ${ }^{2,3}$ Department of Agrotechnology, Faculty of Agriculture Andalas University, Indonesia \\ *Corresponding Author
}

\begin{abstract}
Karamunting plant is one of the biodiversity that must be developed because it has potential as phytopharmaca. The lack of public attention to the preservation and conservation of karamunting plants causes the scarcity of these plants, so it is necessary to do conservation in the form of propagation in vitro. One of the first steps that can be done is to get a callus induction protocol of karamunting plants. This study aim is to obtain a callus induction protocol for karamunting plants using 2,4D, TDZ and BAP growth regulators in vitro. This research was conducted in October to December 2019, at the Tissue Culture Laboratory of the Faculty of Agriculture, Andalas University, Padang. This experiment was compiled based on a Completely Randomized Design (CRD).The treatment used was MS media with a combination of 2,4D, $B A P$, and Thidiazuron concentrations, namely: $A=2.5 \mathrm{ppm} 2,4 \mathrm{D}, \mathrm{B}=5.0 \mathrm{ppm} 2,4 \mathrm{D}, \mathrm{C}=2.5 \mathrm{ppm} 2,4 \mathrm{D}+1$ ppm BAP, $D=5.0$ ppm 2,2D + 1 ppm BAP, $E=2.5 \mathrm{ppm} \mathrm{2,4D+2} \mathrm{ppm} \mathrm{TDZ,} F=5.0 \mathrm{ppm} 2,4 \mathrm{D}+2 \mathrm{ppm}$ TDZ. Explants in the form of karamunting leaves from seed germination in vitro. Based on the results of the study found the influence of growth regulators $B A P, 2.4 D$ and $T D Z$ on the percentage of explants forming callus, callus texture and karamunting callus color. By administering 2.5 ppm 2,4D + 1 ppm BAP, 5.0 ppm 2,2D + 1 ppm BAP and 2.5 ppm 2,4D + 2 ppm TDZ are able to produce a 100\% callus percentage. The 5.0 ppm 2,4D + 2 ppm TDZ treatment produced crumb callus with the highest percentage which was $90 \%$, and 5.0 ppm 2,4D was able to produce compact callus with the highest percentage which was $100 \%$ and the 2.5 ppm 2,4D treatment, $2.5 \mathrm{ppm}$ 2,4D and $5.0 \mathrm{ppm}$ 2,4D + 2 ppm TDZ produce white callus with the highest percentage that is $100 \%$ and 2.5 ppm 2,4D treatment +1 ppm BAP produces green callus with the most percentage which is $75 \%$. While for the first time the callus appeared there was no effect of some concentrations of BAP, TDZ and 2,4D.
\end{abstract}

Keywords — callus, conservation, induction, karamunting, phytopharmaca,

\section{INTRODUCTION}

Karamunting (Rhodomyrtus tomentosa) is a plant that has the potential as a biopharmaca plant because it has been proven to have medicinal properties in every part of the plant. Several compounds in karamunting such as flavonoids as antibacterial and antioxidant, saponin as an antiseptic, tannin as an astrigent that is able to cover the skin pores and light bledding [1] Karamunting root can be beneficial to increase platelet count, fibrinogen level, and contractile muscle of smooth blood vessels. Caramunting fruit can increase the level of hemoglobin and the number of red blood cells (cause adaptive effects), increase antianoxic, cold and fatigue resistance[2]. Some alkaloid compounds are efficacious as anti-diarrhea, anti-diabetic, anti-microbial and anti-malaria, and contain flavonoid compounds to accelerate wound healing by slowing the onset of cell necrosis, increasing the strength of collagen fibers and preventing cell damage[3]. Karamunting also functions as a fever reliever (antipyretic), pain reliever (analgesic), laxative urine (diuretic), relieving swelling, blood flow and stopping bleeding (hemostasis)[4]

In recent years karamunting began to be difficult to find, this happened because there was no community effort to preserve and cultivate it. Other things that can cause these plants to become scarce are land clearing, forest burning and land conversion. So that scarcity of karamunting plants does not continue, it is important to do conservation, one of the conservation steps that can be done is propagation or conservation (short-term storage) in vitro.

In vitro conservation method is one of the first steps in conservation activities, namely by finding the right 
media for the growth of karamunting in vitro. Conservation is carried out in an effort to manage natural resources wisely based on conservation. Conservation of genetic resources needs to be done in order to preserve and preserve the existence of karamunting. Conservation in vitro is divided into short-term, medium-term and longterm (cryopreservation) conservation. Short-term conservation technique or often called the optimal growth technique is a technique of storing planting material in the media and optimum conditions so that explants can grow optimally. Propagation of plants with tissue culture techniques has been done for plants of high economic value or plants that are classified as rare and difficult to propagate conventionally.

Callus induction is one method of tissue culture that is done by stimulating cell division continuously from certain plant parts such as leaves, roots, stems, and so on by using growth regulators to form cell mass. The cell mass (callus) will then regenerate through organogenesis or embryogenesis to become a new plant. In guava callus induction, giving 2,4D growth regulators with a concentration of 5 ppm and 5 ppm 2,4-D + 1 ppm BAP is the best treatment to induce guava callus at 1-2 MST, then by giving $2.5 \mathrm{ppm} 2,4-\mathrm{D}+2 \mathrm{ppm} 2$-Ip is the best treatment in inducing compact callus at 4 MST[5]. Then the results of by administering 2,4-D growth regulators with TDZ gives an influence on the formation of callus in jatropha (Jatropha curcas L.) plants, where at a concentration of 5 ppm 2,4-D + 1 ppm TDZ can produce the fastest callus emergence time, whereas by giving 2.5 ppm 2,4-D + 1 ppm TDZ produces the percentage of formation highest callus in jatropha plants[6]

The purpose of this study was to obtain a callus induction protocol for karamunting plants using 2,4D, TDZ and BAP growth regulators in vitro.

\section{MATERIAL ANDMETHOD}

\subsection{Implementation Research}

This research was conducted in October to December 2019, at the Tissue Culture Laboratory of the Faculty of Agriculture, Andalas University, Padang. The tools used in this study are laminar air flow cabinet, hot plate, magnetic stirrer, scales, measuring flask of various sizes, pasteur pipettes, ovens, erlenmeyers, goblets, stirring glasses, culture bottles, test tubes, petri dishes, spatulas, scissors, scissors rubber band, aluminum foil, scalpel, tweezers, autoclave, bunsen, hand spayer, $\mathrm{pH}$ paper, label paper, camera, stationery, and clear plastic.

The materials used are nodes and karamunting leaves obtained from seed germination in vitro, MS media, sucrose, bacto agar, $\mathrm{pH}$ regulating solution, $70 \%$ alcohol, 96\% alcohol, distilled water, bayclin (bleach containing the active ingredient sodium hypochlorite 5, 25\%), spritus, growth regulators BAP, 2,4D, and Thidiazuron, detergents, duct tape, label paper, aluminum foil, and HVS paper.

This experiment was compiled based on a Completely Randomized Design (CRD). The treatments used were MS media with a combination of 2,4D, BAP, and Thidiazuron concentrations, namely:

$\mathrm{A}=2.5 \mathrm{ppm} 2,4 \mathrm{D}$

$\mathrm{B}=5.0 \mathrm{ppm} 2,4 \mathrm{D}$

$\mathrm{C}=2.5 \mathrm{ppm} 2,4 \mathrm{D}+1 \mathrm{ppm} \mathrm{BAP}$

$\mathrm{D}=5.0 \mathrm{ppm} 2,2 \mathrm{D}+1 \mathrm{ppm} \mathrm{BAP}$

$\mathrm{E}=2.5 \mathrm{ppm} 2,4 \mathrm{D}+2 \mathrm{ppm} \mathrm{TDZ}$

$\mathrm{F}=5.0 \mathrm{ppm} 2,4 \mathrm{D}+2 \mathrm{ppm} \mathrm{TDZ}$

Thus there were 6 treatments, each treatment was repeated 5 times so that there were 30 experimental units. Each experimental unit consisted of 2 bottles so that the number of bottles used was 60 bottles. In each culture bottle 2 explants were planted and all were observed. The observational data were analyzed using the F test and when significantly different it was followed by DMRT at the $5 \%$ level.

Tools such as petridish, scalpel, culture bottles, tweezers, and other equipment are washed with detergent and rinsed thoroughly, then the bottle is immersed in $20 \%$ bayclin for 24 hours, then sterilized in an autoclave at a pressure of 15 Psi (pounds per square inch $=$ pressure on an area of 1 inch) with a temperature of $121^{\circ} \mathrm{C}$ for about 20 minutes. Tools other than culture bottles are wrapped in HVS paper and then wrapped in clear plastic before being put into the autoclave. The water in the autoclave is changed every time you use it. The tools used after sterilization are stored in the oven until used. Laminar air flow is sterilized using UV light for 1 hour before planting and sprayed with $70 \%$ alcohol each time it will be used and after use.

\subsection{Media Making}

The media used is MS media. The composition of MS media can be seen in Appendix 3. How to make MS media with a volume of $1 \mathrm{~L}$ is inserted $800 \mathrm{ml}$ of sterile aquadest into a $1 \mathrm{~L}$ size erlenmeyer, then put a solution of macro stock, micro stock, iron stock, $\mathrm{Mg}$ stock, and vitamins according to raw requirements for making MS media. $30 \mathrm{~g}$ / L sucrose was added, and myo-inositol $100 \mathrm{mg} / \mathrm{L}$, then sufficient media volume was approached to 1 liter. Furthermore, the treatment media solution was divided 
into 6 at $250 \mathrm{ml}$ size erlenmeyer. After that added growth regulators 2,4D, BAP and TDZ according to each treatment, then the $\mathrm{pH}$ of the solution was measured with $\mathrm{pH}$ paper, the $\mathrm{pH}$ of the solution ranged from 5.6 to 5.8 and if the $\mathrm{pH}$ of the solution was less than 5.6 then added $\mathrm{NaOH} 0,1 \mathrm{~N}$ and if the $\mathrm{pH}$ of the solution is more than $5.8,0.1 \mathrm{HCl}$ of $\mathrm{HCl}$ is added. Then bacto is added so that 8 $\mathrm{g} / \mathrm{L}$ which has previously been divided by six and added to each treatment. Finally the media is heated on a hot plate until it boils. After the media boils the solution is poured into a culture bottle as much as $20 \mathrm{ml} /$ bottle. Then the bottle is closed using glass plastic and tied with a rubber band. After that, the media was sterilized in an autoclave at $121^{\circ} \mathrm{C}$, a pressure of 15 Psi for 15 minutes. The media is stored in a culture rack before planting.

\subsection{Preparation of explants}

In the preparation of explants using explants as a result of in vitro karamunting germination using leaf explants (Figure 1). Seed germination was carried out on MS +1 ppm GA3 media. Sterile leaf explants from karamunting germination in vitro can be seen in Figure 2.

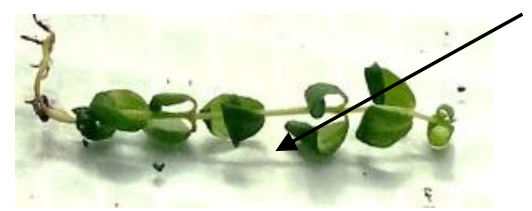

Fig.2. Leaf sterile explants used as a result of karamunting germination in vitro

\subsection{Planting}

Young leaves are cut at the tip and base of the leaf so that the tip and base of the leaf is the injured part of the leaf. Leaf explants were put into culture bottles containing treatment media using tweezers. Then the bottle is closed using a sterile plastic before and tied with rubber. Planting is carried out in a Laminar Air Flow Cabinet (LAFC) which has been previously exposed to UV for 1 hour and is equipped with the tools and materials needed to be sprayed first with $70 \%$ alcohol before being forced into LAFC. Culture bottles are arranged on a culture rack with a temperature of $\pm 25^{\circ} \mathrm{C}$.

\subsection{Observation}

\subsubsection{Soft start time (HST)}

Observation Aiming for the first day of explants forming callus from each treatment combination. Observations were made by observing the development of explants starting from the day of planting until the formation of callus formed from leaf injury.

\subsubsection{Percentage of Forms Forming Callus (\%)}

This observation aims to see the ability of explants to form callus. Observations were made from the first week to the day when there were no more explants forming callus.

$$
\begin{aligned}
\% \text { Eksplan forming callus }= & \sum \text { explants forming callus } \\
& \sum \text { planted explants }
\end{aligned}
$$

\subsubsection{Callus Texture}

Callus texture was visually observed, the part observed was the outer shape of the callus by observing each sample from outside the culture bottle. The observations were documented using a digital camera and explained descriptively.

\subsubsection{Callus Color}

Observation of color is done by observing the change in color of the callus. Observation of callus color was done by comparing callus with Muncle color chart paper for plant tissue, documented using a digital camera and explained descriptively.

\section{RESULTS ANDDISCUSSION}

\subsection{Callus Time (HST)}

The results of the analysis of variance showed that the combination of several concentrations of 2,4-D, BAP and TDZ had no effect on the day of callus appearing on caramunting leaf explants. When the karamunting call appears, it can be seen in Table 1.

Table 1. Time of callus emergence in caramunting leaf explants by treating several concentrations of $2,4 D, B A P$ and TDZ

\begin{tabular}{ll}
\hline Treatment & Callus Time (HST) \\
\hline 2,5 ppm 2,4D & 18.55 \\
5,0 ppm 2,4D & 17.70 \\
2,5 ppm 2,4D + 1 ppm BAP & 19.65 \\
5,0 ppm 2,4D + 1 ppm BAP & 19.70 \\
2,5 ppm 2,4D + 2 ppm TDZ & 20.37 \\
5,0 ppm 2,4D + 2 ppm TDZ & 21.00 \\
\hline
\end{tabular}

Data differ significantly based on $\mathrm{F}$ test of $5 \%$ level

The observations in table 1 show that callus in karamunting leaf explants appeared on days 17.7-21.0 days after planting. Karamunting callus induction callus is relatively long compared to plants with the same family. Guava plants need about 7 DAP to induce callus[5].Callus induction in wheat plants was relatively fast at around 4 HST using explant of young embryos[7]

ZPT of the auxin and cytokinin group given is able to trigger the division so that the process of callus formation can work. In addition, the emergence of the callus is 
thought to be due to increased endogenous auxin content in the leaves due to the addition of exogenous auxin. Manyauxin is synthesized in the apical bud meristematic tissue and young leaves, so that in meristematic young leaves near the end of the stem, the auxin levels are high. The appearance of callus on karamunting leaves is marked by the swelling of explants in the wound site or leaf bone[8].

Callus formation occurred because of the injury given to the explant so that the cells in the explant would repair the damaged cells. The initial stage is an increase in cell wall permeability and water absorption, so that cells will swell then cell division will occur which will form a callus. Callus morphogenesis depends on the balance of auxin and cytokinin in the media[9]. The interaction between plant endogenous growth regulators and exogenous growth regulators absorbed in the media will determine the direction of callus development [10].Callus formed more quickly when auxin concentrations increased. Callus usually appears first in the injured explant area. The presence of injury in explants makes it easier for exogenous ZPT to diffuse into the tissues and works together with endogenous ZPT to form callus by stimulating cell division, especially in the wound area.[11]. The emergence of callus on the injured part is also due to the stimulation of explant tissue to cover the wound that begins with cell wall expansion and water absorption, then the cell will carry out cell division[12].

\subsection{Percentage of Forms Forming Callus (\%)}

The results of the analysis of variance showed that the combination of several concentrations of 2,4D, BAP and TDZ had an influence on the percentage of callus formation in karamunting explants. The percentage of karamunting callus formation can be seen in Table 2 .

Table 2. Percentage of Callus Formation in Karamunting Explants with Treatment of Several Concentrations of 2,4D, BAP and TDZ

\begin{tabular}{lrl}
\hline \multicolumn{1}{c}{ Treatment } & $\begin{array}{c}\text { Percentage } \\
\text { Callus }(\%)\end{array}$ & of \\
& $45 \mathrm{~b}$ \\
\hline 2,5 ppm 2,4D & $30 \mathrm{~b}$ \\
5,0 ppm 2,4D & $100 \mathrm{a}$ \\
2,5 ppm 2,4D + 1 ppm BAP & $100 \mathrm{a}$ \\
5,0 ppm 2,2D + 1 ppm BAP & $100 \mathrm{a}$ \\
2,5 ppm 2,4D + 2 ppm TDZ & $55 \quad \mathrm{~b}$ \\
5,0 ppm 2,4D + 2 ppm TDZ &
\end{tabular}

Figures followed by the same lowercase indicate significantly different based on the DMRT test at 5\% level
Treatment of $2.5 \mathrm{ppm} 2,4 \mathrm{D}+1 \mathrm{ppm}$ BAP, 5.0 ppm 2,2D + 1 ppm BAP and 2.5 ppm 2,4D + 2 ppm TDZ were able to produce the highest percentage of callus that is $100 \%$ and $5.0 \mathrm{ppm}$ treatment $2,4 \mathrm{D}$ produces the lowest callus percentage of $30 \%$. This shows that $2.4 \mathrm{D}$ growth regulators work more optimally when combined with cytokines such as BAP and TDZ in the formation of callus in karamunting explants.

The use of different ZPT gives a variety of responses to each explant individual. This is due to the interaction between endogenous hormones in plant tissue and given exogenous growth regulators[13].Addition of $2.4 \mathrm{D}$ in the media will stimulate cell division and enlargement in the explants so as to stimulate callus formation[14]. The addition of BAP into the media was able to play an active role in the growth and ploriferation of callus[15]. Growth regulating substances which are very influential in the formation of callus are auxin and cytokines, in this case 2,4D with BAP and Kinetin which are able to increase endogenous ZPT content in cells so that they are able to trigger growth and tissue development.. Very active growth substances which influence the formation of callus are auxin and cytokinin, in this case 2,4D with BAP and Kinetin which are able to increase endogenous ZPT content in cells so that they are able to act as a trigger for tissue growth and development[16]

Formation of regenerable callus in plants generally depends on genotype, source of explants, physiological conditions of donor plants, tissue type, media, type and concentration of PGR, and the interaction of these factors [17] The use of auxin is able to activate the transduction signal so that cells can reorganize gene expression and induce cell division to callus growth and somatic embryogenesis. The interaction between endogenous and exogenous ZPT will determine the direction of culture development. The addition of auxin to the medium will change the endogenous ZPT ratio which then becomes a determining factor for the growth process and morphogenesis of explants. Embryogenic callus induction generally uses media with auxin content which has strong activity[18].

\subsection{Callus Texture}

Callus is a disorganized collection of cells and occurs because of a very active division. Stimulation of endogenous hormones or growth regulators that are added (exogenous) causes cell metabolism to become active, in such circumstances the tissue is said to be undergoing dedifferentiation. This situation continues during callus proliferation[19]. Callus that has a crumb texture grows 
apart into small pieces, has a lot of water content, easily separated [20]. Callus texture of caramunting leaf explants can be seen in Table 3 .

Table 3. Callus texture of karamunting plants at 2,4D, $B A P$ and TDZ concentrations

\begin{tabular}{ccccc}
\hline \multirow{2}{*}{ Treatment } & \multicolumn{3}{c}{ Callus texture (\%) } \\
& Crumb & \multicolumn{2}{c}{ Compact } \\
\hline 2,5 ppm 2,4D & 20 & $\mathrm{~cd}$ & 80 & $\mathrm{a}$ \\
$5,0 \mathrm{ppm} \mathrm{2,4D}$ & 0 & $\mathrm{~d}$ & 100 & $\mathrm{a}$ \\
2,5 ppm 2,4D + 1 ppm BAP & $75 \mathrm{ab}$ & 25 & $\mathrm{c}$ \\
$5,0 \mathrm{ppm} \mathrm{2,2D} \mathrm{+} \mathrm{1} \mathrm{ppm} \mathrm{BAP}$ & $45 \mathrm{bc}$ & 55 & $\mathrm{~b}$ \\
2,5 ppm 2,4D + 2 ppm TDZ & $80 \mathrm{a}$ & 20 & $\mathrm{c}$ \\
$5,0 \mathrm{ppm} \mathrm{2,4D} \mathrm{+} \mathrm{2} \mathrm{ppm} \mathrm{TDZ}$ & $90 \mathrm{a}$ & 10 & $\mathrm{c}$ \\
\hline
\end{tabular}

The number followed by the same lowercase letter in the column shows no significant difference based on the DMRT test at $5 \%$ level

The results showed that with some $2,4 \mathrm{D}$ treatment, BAP and TDZ were able to produce crumb and compact callus. The $5.0 \mathrm{ppm} 2,4 \mathrm{D}+2 \mathrm{ppm}$ TDZ treatment produced crumb callus with the highest percentage which was $90 \%$, and 5.0 ppm 2,4D was able to produce compact callus with the highest percentage which was $100 \%$. The combination of 2,4-D $0.3 \mathrm{mg} / 1+\mathrm{BA} 0.1 \mathrm{mg} / 1$ is the best treatment that can produce a more crumb callus texture in plants Dutch teak[21]. Callus texture is a marker of the quality of a callus. The texture of the callus can vary from compact to weak, depending on the type of plant used, the composition of nutrient media, growth regulators and the environmental conditions of culture[23]. The formation of crust structured callus is triggered by the presence of endogenous auxin hormones that are produced internally by explants that have arisen to form the callus[23]. The formation of crumb callus is also influenced by the addition of cytokinins (BAP) in media.

The formation of crust structured callus is triggered by the presence of endogenous auxin hormone which is produced internally by explants that have arisen to form the callus. The formation of crumb callus is also influenced by the addition of cytokinins (BAP) in media that already contains auxin9[23]. The presence of cytokinins can increase cell division in the cytokinesis process, in addition ZPT acts as a trigger especially when RNA and protein synthesis will increase cell division to form callus[21]. The formation of crumb callus is the result of increased cell division activity

The formation of crumb-textured callus in this study was thought to be triggered by the presence of high auxin hormone, in this case 2,4-D[22]. The addition of 2,4$\mathrm{D}$ causes cells to be more actively dividing and enlarging to produce crumb callus. Visually, crumb callus is formed in explants, the cells are small and clustered, the bonds between cells appear to be tenuous, if taken with tweezers, they break easily and some are attached to the tweezers[24]. The crumb callus texture is considered good because it makes it easy to separate into single cells so that the effort to multiply in terms of the number of callus will be easier[25].

In addition to producing crumb callus, karamunting explants also produce a compact callus. Compact callus has cells that look elongated and overlap together, from callus assemblages, and have the potential to develop toward organogenesis and not potentially become somatic embryos[26]. Compact callus which has a dense tissue arrangement, contains a lot of water, greenish color and has meristemoid tissue is very supportive for micropopagation that produces plantlets and for shoot culture purposes[27]. Callus texture produced by the combination treatment of several growth regulators $2,4 \mathrm{D}$, TDZ and BAP can be seen in Figure 2
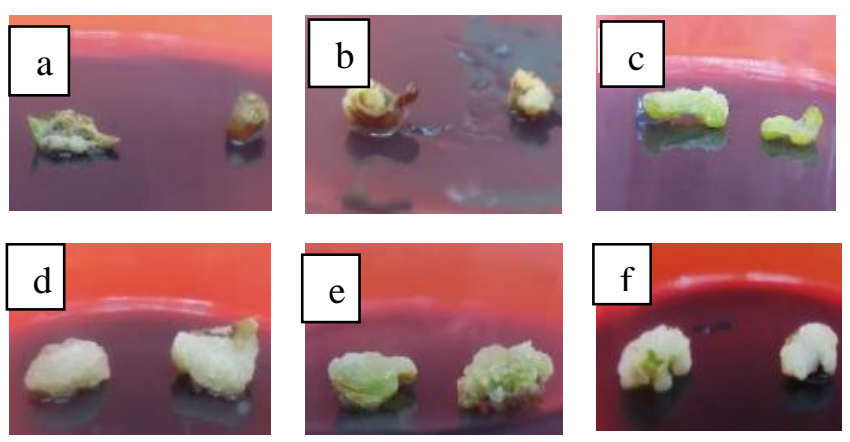

Fig 2. Crumb callus texture produced at several concentrations of growth regulator $2,4 D, T D Z$ and BAP (a) Crumb textured callus at $2.5 \mathrm{ppm} 2,4 \mathrm{D}$ (b) Callus at 5.0 ppm 2,4D (c) Callus at a treatment of 2.5 ppm 2,4D + 1 ppm BAP (d) Callus at a treatment of 5.0 ppm $2.2 D+1$ ppm BAP (e) Callus at treatment $2.5 \mathrm{ppm} 2,4 \mathrm{D}+2 \mathrm{ppm}$ TDZ and $(F)$ Callus at treatment 5.0 ppm 2,4D + 2 ppm $T D Z$

\subsection{Callus Color}

The indicator of explant development in in vitro culture in the form of callus color and texture is used to describe the visual appearance of the callus so that it can be seen that the cell is still actively dividing or has died. Karamunting callus explant color with several treatments of ZPT 2,4D. BAP and TDZ can be seen in Table 4. 
Table 4. Color of Karamunting Callus with several treatments of growth regulator 2,4D, BAP and TDZ

\begin{tabular}{lcc}
\hline \multicolumn{1}{c}{ Treatment } & \multicolumn{2}{c}{ Color of Callus (\%) } \\
\cline { 2 - 3 } & White & Green \\
\hline 2,5 ppm 2,4D & $100 \mathrm{a}$ & $0 \mathrm{~b}$ \\
$5,0 \mathrm{ppm} \mathrm{2,4D}$ & $100 \mathrm{a}$ & $0 \mathrm{~b}$ \\
2,5 ppm 2,4D + 1 ppm BAP & $25 \mathrm{~b}$ & $75 \mathrm{a}$ \\
5,0 ppm 2,2D + 1 ppm BAP & $85 \mathrm{a}$ & $15 \mathrm{~b}$ \\
2,5 ppm 2,4D + 2 ppm TDZ & $80 \mathrm{a}$ & $20 \mathrm{~b}$ \\
$5,0 \mathrm{ppm} 2,4 \mathrm{D}+2 \mathrm{ppm} \mathrm{TDZ}$ & $100 \mathrm{a}$ & $0 \mathrm{~b}$
\end{tabular}

Figures followed by the same lowercase indicate no significant difference based on the DMRT test at 5\% level

Table 4 shows that explants in karamunting leaves are capable of producing white and green callus. In the treatment of $2.5 \mathrm{ppm} 2,4 \mathrm{D}, 2.5 \mathrm{ppm} 2,4 \mathrm{D}$ and $5.0 \mathrm{ppm}$ $2,4 \mathrm{D}+2 \mathrm{ppm}$ TDZ produced the highest white callus with

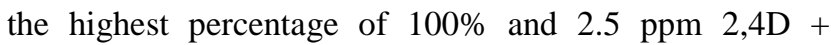
treatment $1 \mathrm{ppm}$ BAP produces the highest green callus with a percentage of $75 \%$. The color of the callus is also an indicator of callus growth. The white callus is embryogenic tissue that does not yet contain chloroplasts, but has a high starch content [28]. The callus color identifies the presence of chlorophyll in the tissue, the more green the callus color, the more chlorophyll content in the callus [29]. The difference in color of the callus shows the level of development of the callus. Callus color indicates the presence of chlorophyll in tissues, where the more green the callus color, the more chlorophyll content it has and the white color in the callus indicates the callus condition is still quite good[24]. The green color in callus is a result or effect of cytokinin in the formation of chlorophyll. Plant growth regulators also have a role in the color of the callus[23]. Increasing concentrations of cytokinins are increasingly likely to show a bright green color on a more durable callus. This is related to the role of cytokinins which can slow the process of senesensi (aging) of cells by inhibiting the overhaul of the grains of chlorophyll and protein in cells[24].

\section{CONCLUSIONS}

Based on the results of the study concluded that the influence of growth regulators BAP, 2.4D and TDZ on the percentage of explants formed callus, callus texture and color karamunting callus. By giving 2.5 ppm $2,4 \mathrm{D}+1$ ppm BAP, 5.0 ppm 2,2D + 1 ppm BAP and 2.5 ppm 2,4D +2 ppm TDZ are able to produce a $100 \%$ callus percentage. The $5.0 \mathrm{ppm} 2,4 \mathrm{D}+2 \mathrm{ppm}$ TDZ treatment produced crumb callus with the highest percentage which was $90 \%$, and $5.0 \mathrm{ppm} 2,4 \mathrm{D}$ was able to produce compact callus with the highest percentage which was $100 \%$ and the $2.5 \mathrm{ppm} 2,4 \mathrm{D}$ treatment, $2.5 \mathrm{ppm} 2,4 \mathrm{D}$ and $5.0 \mathrm{ppm}$ $2,4 \mathrm{D}+2 \mathrm{ppm}$ TDZ produce white callus with the highest percentage that is $100 \%$ and $2.5 \mathrm{ppm} 2,4 \mathrm{D}$ treatment +1 ppm BAP produces green callus with the most percentage which is $75 \%$. While for the first time the callus appeared there was no effect of some concentrations of BAP, TDZ and $2,4 \mathrm{D}$.

\section{REFERENCES}

[1] Anief, M. 1997. Tropical Medicine Formulations With Basic Skin Diseases. Yogyakarta: Gadjah Mada University Press.

[2] Djauhariya, E., Hernani. 2004. Medicinal Weed. Jakarta: Seri Agrisehat

[3] Sutomo, Arnida, F. Hernawati., dan M. Yuwono. 2010. Pharmacognostic Study of SimplisiaKaramunting Leaf (Rhodomyrtustomentosa) from Pelaihari South Kalimantan. Science and Applied Chemistry 1:38-50.

[4] Dalimartha, S. 2006. Atlas of Indonesian Medicinal Plants, Revealing the Wealth of Indonesian Medicinal Plants. Jakarta: NiagaSwadaya

[5] Rivai. R. R. 2013. Callus Induction and Somatic Embryo of Red Guava Plant (Psidium guajava L). Skripsi. InstitutPertanian Bogor

[6] Lizawati. 2012. Embryogenic Callus Induction from Apical Shoots Exploration of Jatropha Curcas (Jatropha curcas L.) using 2,4-D and TDZ. University of Jambi Faculty of Agriculture. 1(2) :75-87

[7] Setiawan, RB. 2015. Induction of mutation of wheat plants (Triticum aestivum L.) Through gamma ray irradiation in vitro for tolerance to high temperatures. Thesis. Bogor Agricultural Institute. $106 \mathrm{Hal}$

[8] Campbell dan Reece. 2014. Biology. Jakarta: Erlangga.

[9] Sitorus M, ED Hastuti, N Setiari. 2011. In vitro Callus Binahong (Basella rubra L.) Induction on Murashige\& Skoog Media with Different Sucrose Concentrations.Bioma 13(1): 17.

[10] Asnawati, Wattimena G.A., Machmud M., Purwito A. 2002. Study of regeneration and production of mesophyll protoplast leaves of several potato plant clones (Solanum tuberosum L.). Bul.Agron. 30(3):87-91.

[11] Permadi AB, Santoso IB \&Kamsinah. 2014. Efforts to Spur Callus Formation from Arachis hypogaea with 2,4-D and Kinetin. Thesis. Purwokerto: Faculty of Biology UNSOED

[12] George, E.F. And P.D. Sherrington. 1984. Plant Propagartion by Tissue Cultur. Handbook and Directory of Commercial Laboratories. Exegenetic Limited. England.

[13] Yulianti. 2015. Callus Induction of Several Orange Genotypes (Citrus Sp.) Using 2,4-D in vitro. Thesis. Padang. Andalas University Faculty of Agriculture.

[14] Rahayu, Bekti. S, dan Endang. A. 2003. "Effect of 2,4Dichlorophenoxyacetic Acid (2,4-D) on Callus Formation and Growth and Content of Callus Culture Acalyphaindica L 
". Biofarmasi 1(1): 1-6

[15] Sari, Novita, Evie Ratnasari, Isnawati. 2013. "Effects of Addition of Various 2,4-Dichlorophenoxyacetate (2,4-D) and 6- BensilAminopurin (BAP) Concentration to MS Media on Texture and Color of Callus Teak Explants Callus (Tectonagrandis Linn. F.)" JUL". LenteraBio2(1):69-73

[16] Lestari, E. G. (2011). The Role of Growth Regulatory Substances in Plant Propagation through Tissue Culture.JurnalAgrobiogen. 7(7):63-68

[17] Gray DJ. 2005. Propagation from nonmeristematictissue :Nonzygotic embryogenesis, p. 187-200. In :Trigiano RN and Gray DJ (Eds.). Plant Development and Biotecnology. CRC Press. United States of America

[18] Oktavia F, Siswanto, Budiani A, Sudarsono. 2003. Direct somatic embryogenesis and regeneration of arabica coffee plants (Coffea arabica) from various explants. Menara Perkebunan. 71(2):44-55.

[19] Wetter, L.R., Constabel F. 1991. Plant Tissue Culture Method. Widianto MB, translator. Bandung (ID): ITB Pr. Terjemahandari: Plant Tissue Culture Methods.

[20] Sitorus, E.N., E.D. Hastuti dan N. Setiari, 2011. Binusong (Basella rubra L.) Induction Callus In Vitro In Murashige\& Skoog Media With Different Sucrose Concentrations. BIOMA, 13(1): 1-7.

[21] Syahid, Sitti Fatimah, Natalini Nova Kristin, dan DeliahSeswita. 2010. "Effect of Media Composition on Growth of Callus and Tannin Levels from Leaves of Dutch Teak (GuazumaulmifoliaLamk) In Vitro ".Jurnal Litri.16(1) : $1-5$.

[22] Pierik, R.I. 1987. In vitro Culture oF Higher Plants. Netherlands: MartinusMartinusNijhoff Publishers

[23] Widyawati, dan Geningsih. 2010. The Effect of NAA and BAP Concentration Variations on the Distance of Fence Callus Induction. Thesis. Surakarta SebelasMaret University.

[24] Andaryani, S. 2010. Study of the Use of Various BAP and 2,4-D Concentrations in Jatropha curcas L. Induction Callus Induction. Thesis. FapertaSebelasMaret University. Surakarta

[25] Thomy, Z. 2012. Effect of Plant Growth Regulator 2,4-D and BAP on callus Growth of Plants Producing Gaharu(Aquilaria malaccensisLamk.). Prosiding Seminar Hasil Nasional Biologi. Medan

[26] Rai, M.K., Jaiswal V.S., Jaiswal U. 2009. Shoot multiplication and plant regeneration of guava (Psidium guajava L.) from nodal explants of in vitro raised plantlets. J. Fruit Ornam. Plants Res. 17(1):29-38.

[27] Manuhara, Y.S.W. 2001. Regeneration of mustard plant (Brassica juncea L. Var Marakot). Through tissue culture techniques. Jurnal MIPA. 6(2): 127-130.

[28] Ariati,S. N. 2012.Callus Induction of Cocoa (Theobroma cacao L.) on MS Media with the addition of 2,4-D, BAP and Coconut Water.Jurnal Natural Science. 1(1): 78-84

[29] Dwi,N.M. 2012. Effect of Giving Coconut Water and Various Concentrations of 2,4-D Hormone in MS Medium in Inducing Grape Callus (Vitisvinera L.). Journal of Natural science, 1(1) :53-62. 